\title{
Plant structural changes due to herbivory: Do changes in Aceria-infested coconut fruits allow predatory mites to move under the perianth?
}

\author{
Nayanie S. Aratchige • Maurice W. Sabelis • \\ Izabela Lesna
}

Received: 15 March 2007 / Accepted: 7 September 2007 / Published online: 27 September 2007

(C) Springer Science+Business Media B.V. 2007

\begin{abstract}
Being minute in size, eriophyoid mites can reach places that are small enough to be inaccessible to their predators. The coconut mite, Aceria guerreronis, is a typical example; it finds partial refuge under the perianth of the coconut fruit. However, some predators can move under the perianth of the coconut fruits and attack the coconut mite. In Sri Lanka, the phytoseiid mite Neoseiulus baraki, is the most common predatory mite found in association with the coconut mite. The cross-diameter of this predatory mite is $c .3$ times larger than that of the coconut mite. Nevertheless, taking this predator's flat body and elongated idiosoma into account, it is - relative to many other phytoseiid mites-better able to reach the narrow space under the perianth of infested coconut fruits. On uninfested coconut fruits, however, they are hardly ever observed under the perianth. Prompted by earlier work on the accessibility of tulip bulbs to another eriophyoid mite and its predators, we hypothesized that the structure of the coconut fruit perianth is changed in response to damage by eriophyoid mites and as a result predatory mites are better able to enter under the perianth of infested coconut fruits. This was tested in an experiment where we measured the gap between the rim of the perianth and the coconut fruit surface in three cultivars ('Sri Lanka Tall', 'Sri Lanka Dwarf Green' and 'Sri Lanka Dwarf Green $\times$ Sri Lanka Tall' hybrid) that are cultivated extensively in Sri Lanka. It was found that the perianth-fruit gap in uninfested coconut fruits was significantly different between cultivars: the cultivar 'Sri Lanka Dwarf Green' with its smaller and more elongated coconut fruits had a larger perianth-fruit gap. In the uninfested coconut fruits this gap was large enough for the coconut mite to creep under the perianth, yet too small for its predator $N$. baraki. However, when the coconut fruits were infested by coconut mites, the perianth-rim-fruit gap was not different among cultivars and had increased to such an extent that the space under the perianth became accessible to the predatory mites.
\end{abstract}

\footnotetext{
N. S. Aratchige $\cdot$ M. W. Sabelis $(\bowtie) \cdot$ I. Lesna

Section Population Biology, Institute for Biodiversity and Ecosystem Dynamics (IBED),

University of Amsterdam, Kruislaan 320, Amsterdam, 1098 SM, The Netherlands

e-mail: sabelis@science.uva.nl
} 
Keywords Eriophyidae $\cdot$ Coconut mites $\cdot$ Coconut $\cdot$ Predatory mites $\cdot$ Phytoseiidae $\cdot$ Perianth $\cdot$ Induced response $\cdot$ Indirect plant defence

\section{Introduction}

To reduce the predation risk, some organisms show behavioural or morphological changes that are induced by their predators (Wiackowski and Starońska 1999; Buskirk and McCollum 2000; Oku et al. 2003). Some have adapted to find refuge in such a way that predators cannot reach them. Eriophyoid mites have a worm-like body with a very small cross-section diameter $(40-100 \mu \mathrm{m})$ that allows them to reach concealed plant parts or to live in selfinduced, small plant galls where they find protection from biotic and abiotic stresses (Sabelis and Bruin 1996). The coconut mite, Aceria guerreronis Keifer (Acari: Eriophyidae), feeds on the meristematic tissue beneath the perianth covering the base of the coconut fruit. Here it not only profits from the relatively nutritious value of this tissue, but also from the reduced risk of predation due to the perianth. Among the predatory mites that have been reported to be associated with the coconut mite in Sri Lanka, Neoseiulus baraki AthiasHenriot (Acari: Phytoseiidae) is the most frequently found species (Fernando et al. 2003; Moraes et al. 2004). This species was previously referred to as $N$. aff. paspalivorus (Fernando et al. 2003), but was later confirmed as $N$. baraki (Moraes et al. 2004). It has a flat and elongated idiosoma (Moraes et al. 2004) and we suggest this might make this predator-relative to other phytoseiid mites-better suited to creep into narrow spaces.

When the coconut mites are outside the perianth they are exposed and vulnerable to predators, but under the perianth of the coconut fruit they face less risk of being eaten. In the absence of natural enemies, coconut mite populations may grow exponentially and, consequently, the development of the coconut fruit will be impaired. Therefore, we expect the coconut palms to defend themselves directly against the coconut mites and/or indirectly by promoting the efficiency of predators against these herbivores (e.g. Sabelis et al. 2007). In this article, we investigate whether coconut fruits exhibit a mode of indirect defence that is similar to that observed in tulip bulbs by Lesna et al. (2004). These authors have found that, when tulip bulbs are attacked from within by the eriophyoid mite Aceria tulipae Keifer (Acari: Eriophyidae), bulbs increase the gap between scales to such an extent that predatory mites can enter the interior of the bulbs. This prompted us to hypothesize that mite-infested coconut fruits undergo a change in perianth structure with the effect that predatory mites have better access to the space underneath the perianth and thereby to the coconut mites. To test this hypothesis we measured the gap between the perianth and the surface of coconut fruit ("perianth-fruit gap") when uninfested and when infested by coconut mites, and compared the size of the gap with the size of the predatory mite $N$. baraki.

The perianth functions as a protective cover to the female flower and the tender meristematic zone of the growing coconut fruit. In young coconut fruits (i.e. 1-2 months after fertilization) the perianth is tightly appressed to the surface of the coconut fruit (Howard and Abreu-Rodriguez 1991), but, as the coconut fruit grows, the perianth-fruit gap increases slightly, but apparently just sufficient for the coconut mites to move under the perianth and feed on the meristematic zone of the coconut fruit. Tightness of the perianth (Howard and Abreu-Rodriguez 1991), bract arrangement (Moore 1986) and shape (Mariau 1986) of the coconut fruit have been shown to affect the susceptibility of coconut fruit to the coconut mites. Thus, perianth structure affects the probability of coconut mite infestation, but the extent of the effect depends on the growth phase of the coconut and on the palm cultivar. 
Coconut mites usually do not infest the meristematic zone of unfertilized coconut flowers (Mariau and Julia 1970; Hall and Espinosa-Becerril 1981; Moore and Alexander 1987). After fertilization, coconut fruits of all stages are susceptible to mite attack but in general, peak populations occur in 3- to 7-months-old coconut fruits (Moore and Alexander 1987; Ramaraju et al. 2002; Fernando et al. 2003). For our experiments we used 4-month-old coconut fruits of three cultivars, commonly grown in Sri Lanka. We measured the perianthfruit gap for each of these cultivars when uninfested and when infested by coconut mites. Finally, we compared the size of the gap with that of the predatory mite, N. baraki, to make inferences on accessibility of the space under the perianth to the predators of coconut mites.

\section{Materials and methods}

\section{Perianth-fruit gap measurement}

Four-month-old coconut fruits (i.e. 4 months after fertilization) were collected from palms of the three cultivars: (1) cultivar 'Sri Lanka Dwarf Green' (DG), which has usually small, elongated coconut fruits, (2) cultivar 'Sri Lanka Tall' (SLT) with larger and more roundshaped coconut fruits, and (3) a hybrid 'Sri Lanka Dwarf Green $\times$ Sri Lanka Tall' (DGT). After bringing the coconut fruits to the laboratory they were first split transversely into two halves to remove nut water. This made it easier to dissect the coconut fruit into four longitudinal sections across the perianth (Fig. 1). Dissected coconut fruits with disturbed perianth structure and loosened fibres at the coconut fruit surface were discarded from the measurements.

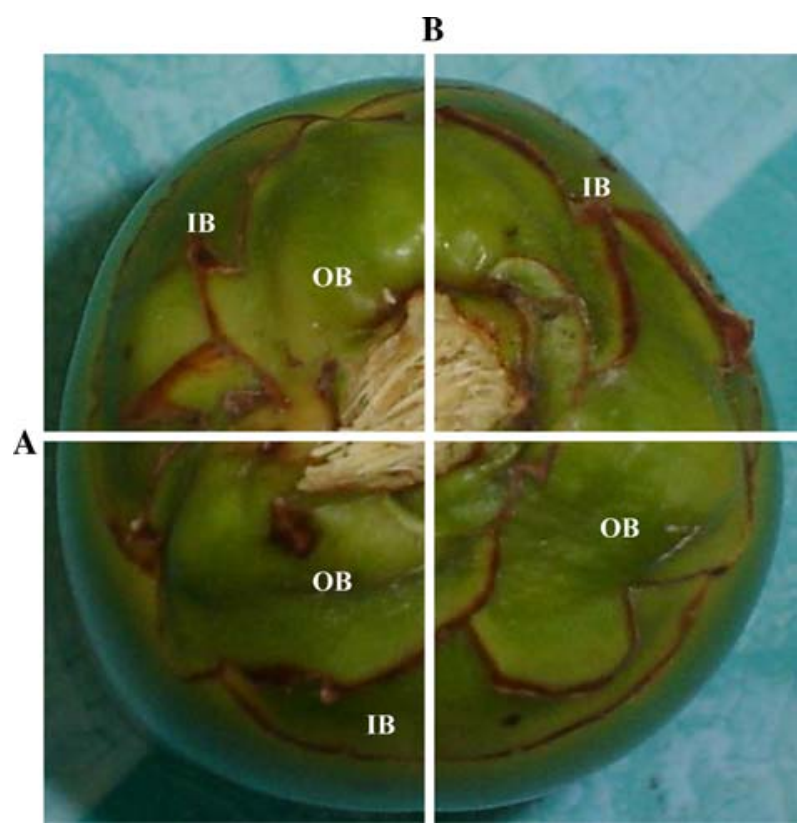

Fig. 1 Bract arrangement of the perianth on a coconut fruit. Longitudinal sections were taken along line A and B. OB-Outer bracts of the perianth, IB-Inner bracts of the perianth 


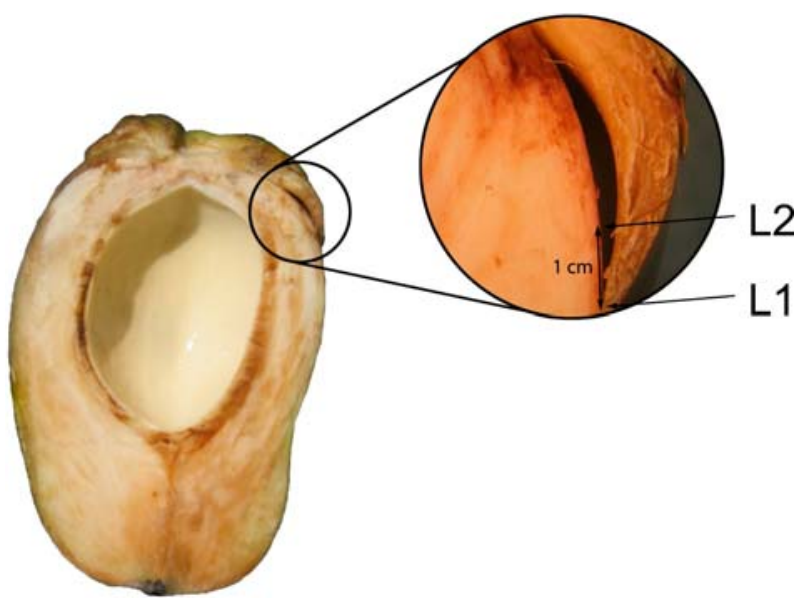

Fig. 2 Longitudinal section of a coconut fruit showing position L1 at the edge of the bract touching the coconut fruit and position L2, $1 \mathrm{~cm}$ away from L1 along the surface of the coconut fruit

After splitting coconut fruits into four sections, the perianth-fruit gap was measured at two different places on each section (Fig. 2) using a stereomicroscope with a graticule. The first measurement (L1) was made at the rim of the perianth where it touches the coconut fruit surface (Fig. 2). The edge of each bract of the perianth has two different positions: (1) the edge that directly touches the surface of the coconut fruit, (2) the edge that overlaps (or is overlapped by) another bract. Measurements were not taken at the latter position, as it was difficult to dissect the coconut fruits along this position of the bract without disturbing the structure of the perianth. The second measurement (L2) was taken $1 \mathrm{~cm}$ away from position L1, higher up along the surface of the coconut fruit (Fig. 2). These two perianth-fruit gaps were measured in 157 infested (61 from SLT, 39 from DG and 57 from DGT) and 114 uninfested (43 from SLT, 28 from DG and 43 from DGT) coconut fruits.

\section{Mite census}

After measuring the gap between the surface of the coconut fruit and the perianth, bracts of each coconut fruit were removed to count the number of mites on the lower surface of each of them as well as on the underlying surface of the fruit. Counts of total number of mobile stages were done under a stereomicroscope. Total number of $N$. baraki was counted, whereas the population level of $A$. guerreronis was estimated by counting the total number of mites from six randomly selected circular $(1 \mathrm{~cm} \varnothing)$ patches, three on the lower side of the perianth and three on the surface of the coconut fruit under the perianth.

\section{Size of the predatory mites}

For $c .30$ min predatory mites were kept in a Petri dish on wet cotton wool, placed on ice to lower the temperature (to $3^{\circ} \mathrm{C}$ ), thereby reducing mite activity. Thickness of the soma was taken as a measure of size. This was assessed for 12 female deutonymphs, just before their last moult, and for 20 adult females, ten of which were 1-day-old since their last moult and the other ten were more-than-5-days-old. Measurements in each stage of predatory mites 
were replicated four times. Because the migratory population of $N$. baraki mainly consisted of adult females (Kumara, unpublished data) and they are more likely to be the first invaders under the perianth of infested coconut fruits, sizes of the larval and protonymphal stages of the predatory mites were not used in our analysis. The other predatory mite that is commonly found under the perianth is $N$. paspalivorus which occurs mainly in the wet zone of Sri Lanka (Fernando, unpublished data). We did not measure the size of $N$. paspalivorus in our study since it does not occur in the dry-intermediate zone where we collected the coconuts.

\section{Statistical analysis}

The perianth-fruit gap (L1) appeared to vary with the position along the perianth rim. The mean thickness of adult female $N$. baraki exceeded the mean value of the measurements taken at four positions along the perianth rim in most coconut fruits. Yet, the soma was less thick than the widest perianth-fruit gap on each coconut fruit. We hypothesized that the predatory mites can find the entrance to the interior of the perianth if there are places with a sufficiently large gap between fruit and perianth. Thus, the mean value of the perianth-rimfruit gap (L1) is less relevant if it concerns perianth accessibility to the predatory mite. Therefore, it was assumed that the widest gap observed from data obtained from four sites on each coconut fruit was the most relevant variable to be taken into account in the data analysis. Generalized Linear Models (GLM) were used to test differences in the perianthfruit gap between main factors (category of coconut fruits i.e. infested and uninfested coconut fruits and cultivar) and to assess the interactions between the main factors.

Using only the data on infested coconut fruits it was further investigated whether the perianth-fruit gap is a predictor of predator/herbivore mite density under the perianth. Regression analyses were performed to assess the relation between the widest perianth-fruit gap and the per nut density of coconut mites under the perianth and the per nut density of predatory mites under the perianth. The difference in the density of coconut mites and predatory mites among cultivars were analyzed using one-way ANOVA on log-transformed data. All analyses were carried out using Minitab ${ }^{\circledR}$, Version 11.

\section{Results}

The mean of the widest perianth-fruit gaps at L1 and L2 in infested and uninfested coconut fruits in three cultivars are shown in Fig. 3. In uninfested coconut fruits these were 41, 68 and $40 \mu \mathrm{m}$ at L1 and 39, 78 and $45 \mu \mathrm{m}$ at L2 in SLT, DG and DGT, respectively, whereas in infested coconut fruits these were 80, 75 and $99 \mu \mathrm{m}$ at L1 and 84, 107 and 94 at L2 in SLT, DG and DGT, respectively. Thus, the perianth-fruit gap at L1 and L2 was significantly higher in infested coconut fruits than in uninfested coconut fruits (Table 1; see also Figs. 3 and 4). No significant difference was observed in the perianth-fruit gap among cultivars at L1. However, the perianth-fruit gap was significantly affected by the cultivar at L2 (Table 1). The interaction between category of the coconut fruit (infested and uninfested) and cultivar was significant at L1, but not at L2 (Table 1). This significant category-cultivar interaction at L1 arises because the increase in perianth-fruit gap due to coconut mite infestation is significant in two cultivars (SLT, DGT), but not in the third cultivar (DG). It should be noted that the perianth-fruit gap of uninfested fruits from the latter cultivar (DG) is very similar to the gap size of infested fruits in the two former cultivars (SLT, DGT) (Fig. 3). 


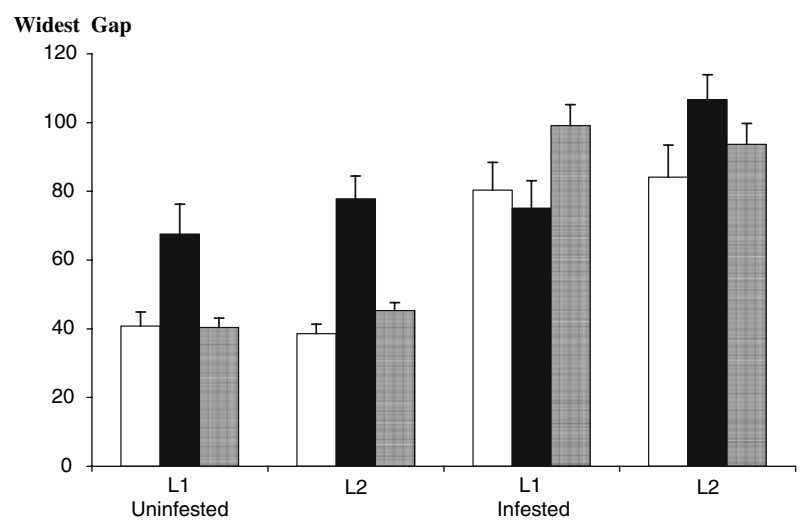

Fig. 3 Mean $( \pm S E)$ of the widest gap at L1 and L2 in infested and uninfested coconut fruits of three cultivars: SLT = 'Sri Lanka Tall' (white rectangles), DG = 'Sri Lanka Dwarf Green' (black rectangles), DGT = 'Sri Lanka Dwarf Green $\times$ Sri Lanka Tall' hybrid (grey rectangles)

Table 1 Analysis of variance of the gap (L1 and L2) between the perianth and the surface of the coconut fruit

\begin{tabular}{|c|c|c|c|c|}
\hline Sources of variance & df & MS & $F$ & $P$ \\
\hline \multicolumn{5}{|l|}{ At L1 } \\
\hline Category & 1 & 254,670 & 33.88 & $<0.001$ \\
\hline Cultivar & 2 & 5,908 & 0.79 & 0.457 \\
\hline Category $\times$ Cultivar & 2 & 40,287 & 5.36 & $<0.01$ \\
\hline Residual & 265 & 7,516 & & \\
\hline \multicolumn{5}{|l|}{ At L2 } \\
\hline Category & 1 & 582,235 & 49.27 & $<0.001$ \\
\hline Cultivar & 2 & 56,586 & 6.87 & 0.001 \\
\hline Category $\times$ Cultivar & 2 & 11,831 & 1.44 & 0.239 \\
\hline Residual & 265 & 8,232 & & \\
\hline
\end{tabular}

Category refers to classification into infested and uninfested coconuts; $\mathrm{df}=$ Degrees of freedom; $\mathrm{MS}=\mathrm{Mean}$ of squares; $P=$ Critical level

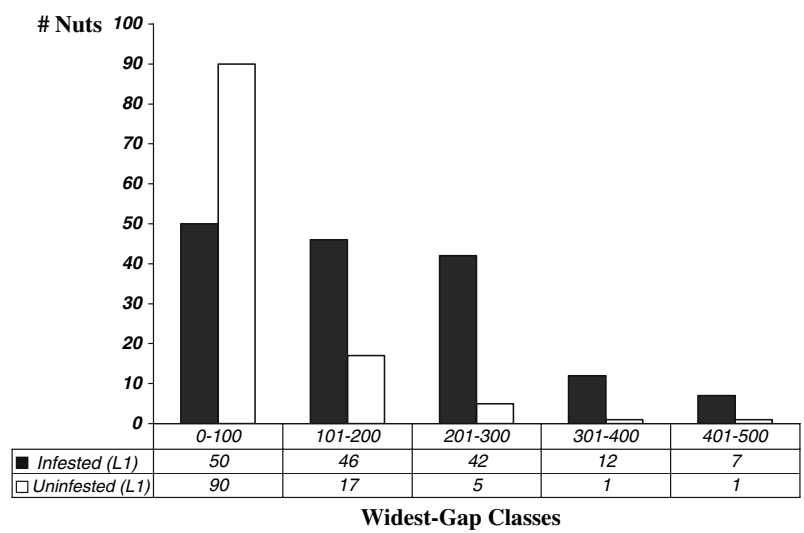

Fig. 4 Frequency distribution of coconut fruits over classes of widest L1 gaps in infested (black rectangles) and uninfested (white rectangles) coconut fruits (all three cultivars together) 
To test whether the widest perianth-fruit gap (L1) is a predictor of mite density under the perianth regression analysis was carried out. Because most infested coconut fruits had predatory mites under their perianth, it was not possible to obtain a sufficiently large sample of coconut fruits that had coconut mites only. A scatter plot of the few data points did not show any conspicious trend. Regression of the number of predatory mites under the perianth on L1 measured on the same coconut fruit did not reveal a significant relation $\left(R^{2}=0.04\right.$, slope $\left.=0.011, P=0.436\right)$. This means that among the infested coconut fruits the perianth-fruit gap is not a reliable predictor of the density of predatory mites under the perianth. The absence of a correlation is not unexpected because the density records are snapshots of a dynamic process involving interactions between predator and prey. Sampling randomly over the time course of such an interaction is bound to show no correlation.

The frequency distribution of coconut fruits over different gap classes showed different patterns in infested and uninfested coconut fruits (Fig. 4). At L1, 79\% of the uninfested coconut fruits had a widest perianth-fruit gap less than $100 \mu \mathrm{m}$ whereas $68 \%$ of the infested coconut fruits had a highest perianth-fruit gap exceeding $100 \mu \mathrm{m}$. These percentages, i.e. $21 \%$ for uninfested fruits and $68 \%$ for infested fruits, are significantly different according to Chi-square analysis of the $2 \times 2$ frequency table that can be constructed from the table below Fig. $4\left(X^{2}=58.63>>10.83\right.$ at $\left.\alpha=0.001\right)$. The frequency distribution of perianthfruit gap at L2 followed the same pattern as that at L1. In conclusion, the gap between perianth and surface of the coconut fruits increased dramatically when infested by coconut mites.

The mean thickness $( \pm \mathrm{SE})$ of the female deutonymphs of $N$. baraki was estimated to be $95 \pm 4 \mu \mathrm{m}(n=12)$. In adult female predatory mites, the mean thickness was $100 \pm 4 \mu \mathrm{m}$ in mites 1-day-old after their last moult $(n=10)$ and $110 \pm 7 \mu \mathrm{m}$ in mites older than 5 days after their last moult $(n=10)$. However, the sizes of deutonymphs and two age classes of adult females were not statistically different from each other.

The number of $A$. guerreronis varied from 0 to 6491 with means of 1,178, 1,302 and 1,093 in six circular patches of $1 \mathrm{~cm}$ diameter in SLT, DG and DGT, respectively (Fig. 5). Their density (per six circular patches of $1 \mathrm{~cm}$ diameter) was not significantly different among the infested cultivars $(P=0.322, \mathrm{df}=2$ and $F=1.14$ for log-transformed data). The number of $N$. baraki ranged from 0 to 55 with means of 9,13 and 8 mites per coconut fruit in SLT, DG and DGT, respectively (Fig. 5). There was a significant difference in the density of $N$. baraki among infested cultivars $(P=0.024$, df $=2$ and $F=3.82$ for $\log$ transformed data): cultivar DG had a significantly higher density of predatory mites than the other two cultivars. We can therefore not exclude the possibility that the densities of coconut mites are blurred by effects of predatory mites. Unfortunately, sample sizes of

Fig. 5 Mean $( \pm S E)$ of the number of coconut mites (white rectangles) and predatory mites (black rectangles) per coconut fruit from three coconut cultivars (SLT, DG, DGT; see legend of Fig. 3)

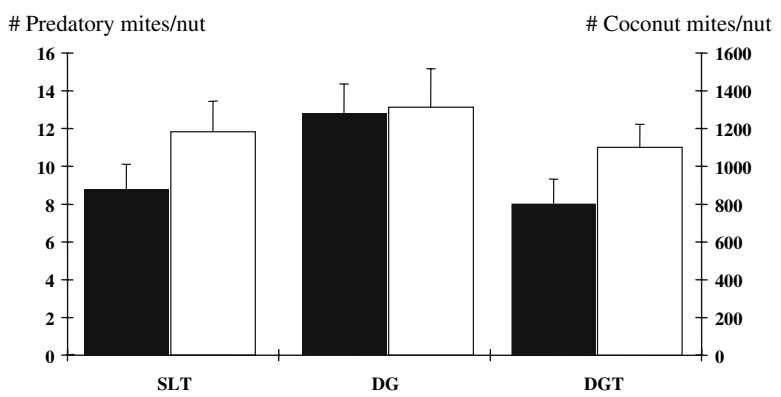

Springer 
coconut fruits 'with coconut mites but no predatory mites' were far too small to warrant further analysis (e.g. in DG there were only five coconut fruits of this type).

\section{Discussion}

We found that the perianth-fruit gap was different among cultivars SLT, DG and DGT of the coconut palm. Except at L1 in infested coconut fruits, among the three cultivars used in our study, cultivar DG had the widest mean gap. In general DG bears smaller and more elongated coconut fruits than the other two cultivars. As observed by Mariau (1977), varieties with small coconut fruits are more susceptible to coconut mites than varieties with large coconut fruits. This may well be because the perianth of the smaller coconut fruits is less firmly attached to the coconut fruit, giving mites better access to the space under the perianth. In our study the highest mean number of coconut mites was also found on DG. However, the density of coconut mites did not significantly differ among cultivars. Therefore, the results of our study did not firmly support the idea that the coconut fruits with larger gap between perianth and the surface of the coconut fruit (in other words fruits with loosely attached perianth) are more susceptible to the coconut mite. It should be noted that the mean widest gap between the perianth and the surface of the uninfested coconut fruits exceeded $40 \mu \mathrm{m}$ in all three cultivars, which is larger than the cross-diameter of adult female coconut mites (36-52 $\mu \mathrm{m}$; Keifer 1965). Hence, the perianth-fruit gap in uninfested coconut fruits of any of the three cultivars is large enough for mature coconut mites to enter the space under the perianth. Hence, we expect the sub-perianth space of the three cultivars in our study to be equally accessible to mature coconut mites.

The widest perianth-fruit gap per uninfested coconut fruit was much less than $100 \mu \mathrm{m}$ (see Fig. 3) in $79 \%$ of the coconut fruits we observed in our study (Fig. 4). However, the mean cross-diameter of the soma of adult female $N$. baraki was $c .110 \mu \mathrm{m}$. Therefore, it is clear that the perianth-fruit gap of most uninfested coconut fruits is not large enough for adult females of $N$. baraki to enter the space under the perianth. This largely applies to the deutonymphs of $N$. baraki as well, since their mean soma cross-diameter is close to $100 \mu \mathrm{m}$. Possibly, larvae and protonymphs of $N$. baraki have a soma small enough to pass the perianth-fruit gap of uninfested coconut fruits. However, juvenile predatory mites are unlikely to be the first invaders under the perianth, because they are much less mobile than adults and because female predatory mites can only lay eggs when there is a sufficient supply of prey. Adult females are therefore more likely to be the first to colonize a coconut, but they cannot enter sub-perianth space unless coconut mites have established. Hence, initially coconut mites experience reduced risk of being eaten by predatory mites when feeding on the tissue beneath the perianth.

Interestingly, we found that the gap in coconut fruits infested by coconut mites was significantly wider than that in uninfested coconut fruits (Fig. 4). Of the infested coconut fruits in our study, $68 \%$ had a perianth-fruit gap above $100 \mu \mathrm{m}$ at L1 which is large enough for $N$. baraki to creep under the perianth. This suggests the following mechanistic hypothesis to be tested by future experimental analysis: when infested by coconut mites, the coconut fruits increase the gap between the perianth and the surface of the coconut fruit to such an extent that the predators can reach their otherwise-concealed prey. Our results on coconuts are consistent with observations by Lesna et al. (2004) on tulip bulbs. When infested by the rust mite, A. tulipae, tulip bulbs become attractive to the predatory mite, Neoseiulus cucumeris Oudemans (Acari: Phytoseiidae) (Aratchige et al. 2004). Having a small crosssectional area, rust mites can easily move into the spaces in between bulbs scales where 
they are in refuge because the bulb scales in the apex (so called 'nose') of the bulbs are too tightly packed for predators to move in. However, in response to damage by rust mites, bulbs start to produce ethylene which triggers the bulbs to widen the gap between scales in the 'nose' of the bulb, apparently to an extent that is just enough to allow the predatory mites to enter the inside of the bulb (Lesna et al. 2004). More importantly, treating the tulip bulbs with an ethylene blocker causes the space between bulb scales to be more narrow: tight enough to prevent access by predatory mites, but definitely not tight enough for the rust mite to enter the inside. Thus, it is not just the feeding damage to the bulb scale tissue that causes widening of the space between bulb scales (Lesna et al. unpublished data). Whether the structural changes in the perianth of coconut fruits in response to coconut mite attack is herbivore-induced plant response or a by-product of necrosis and suberization of the coconut fruit surface due to herbivory, remains to be elucidated, however. The 'byproduct' hypothesis is not supported by the observation that the perianth-fruit gap of uninfested fruits from cultivar DG is very similar to the gap size of infested fruits from the same cultivar, as well as the two other cultivars (SLT, DGT) under study. Thus, coconut mite infestation has no significant effect on perianth-fruit gap in cultivar DG and the space beneath the perianth is always accessible to the predatory mite $N$. baraki, irrespective of coconut mite infestation. Whereas this shows that increased gap size is not a simple consequence of necrosis and suberization of the meristimatic tissue beneath the perianth, it does not disprove this hypothesis (e.g. feeding effects on perianth structure may depend on the structure itself) and-as yet - there is no evidence for the 'induction' hypothesis.

Determining whether or not the changes in perianth structure are induced or not, has wider implications. An induced response indicates a net benefit to the coconut palm and hence a reason why it may have been favoured by natural selection. Such an evolutionary response of the plant requires that the association between the eriophyids and the coconut palm has existed for a long enough time and that eriophyids have represented a selective factor of importance. This may not be true for the Americas because Cocos nucifera was introduced some 500 years ago, whereas A. guerreronis, while native to the Americas, has been first described and discovered as a pest in 1965 (Navia et al. 2005). Moreover, there is insufficient data to make any inference on mite-palm associations for the Asian region. Thus, any speculation on the evolution of induced plant responses in perianth structure rests on the assumption of a sufficiently long association with some eriophyoid species or other herbivore (e.g. tarsonemid mites; see Lawson-Balagbo et al. 2007) small enough to reach the space beneath the perianth. Alternatively, plants ancestral to coconut palms have been selected to induce a generalized 'open-the-gap' response to attack by any herbivore small enough to enter and feed in otherwise tight folds of plant tissue. Another crucial assumption is that there are predators small enough to enter sub-perianth space and capable of controlling coconut mites. This may hold for the predatory mite $N$. baraki since it is frequently found associated with coconut mites (Fernando et al. 2003), but critical tests to prove its biocontrol capacity are still to be done.

For herbivore-induced increase of the perianth-fruit gap to be a plant defense strategy favoured by selection, the benefits should exceed the costs. Clearly, when the perianth-fruit gap is increased, coconut fruits may not only get assistance from predatory mites to combat coconut mites, but they would also become more vulnerable to herbivores that are somewhat larger than eriophyoid mites. This cost may be offset by providing sub-perianth access to a generalist predatory mite, like $N$. baraki, that can feed on (juvenile stages of) slightly larger herbivorous arthropods as well. However, the increased gap width may also provide intraguild predators, such as Proctolaelaps bickleyi (Acari: Ascidae), with access beneath the perianth, as recently shown in an extensive survey in Brazil (Lawson-Balagbo et al. 
2007). Most intraguild predators, including P. bickleyi, are larger than their intraguild prey, and this may either lead to partitioning of refuge space under the perianth depending on predator and refuge size or even to exclusion from the sub-perianth space (Lawson-Balagbo et al. 2007). We therefore hypothesize that the maximum perianth-fruit gap created by the coconut palm represents a compromise between benefits in terms of protection by predatory mites and costs in terms of desiccation, increased diversity of herbivores and impact of intraguild predators of the effective predators of coconut mites.

Acknowledgements We thank Dr F. W. Howard, Dr. Priyanthie Fernando of the Crop Protection Division of the Coconut Research Institute of Sri Lanka and Dr. Devaka Weerakoon of the Department of Zoology, University of Colombo, Sri Lanka for thoughtful comments on the manuscript and Mr. N. G. Premasiri of the Crop Protection Division, Coconut Research Institute of Sri Lanka for his technical support.

\section{References}

Aratchige NS, Lesna I, Sabelis MW (2004) Below-ground plant parts emit herbivore-induced volatiles: olfactory responses of a predatory mite to tulip bulbs infested by rust mite. Exp Appl Acarol 33:21-30

Buskirk JV, McCollum SA (2000) Functional mechanisms of an inducible defence in tadpoles: morphology and behaviour influence mortality risk from predation. J Evol Biol 13:336-347

Fernando LCP, Aratchige NS, Peiris TSG (2003) Distribution pattern of coconut mite Aceria guerreronis and its predator Neoseiulus aff. paspalivorus on coconut palms. Exp Appl Acarol 31:71-78

Hall RA, Espinosa-Bezerril A (1981) The coconut mite, Eriophyes guerreronis, with special reference to the problem in Mexico. Proceedings of the British Crop Protection Conference-Pests and Diseases, British Crop Protection Council, Farnham, UK, pp 113-120

Howard FW, Abreu-Rodriguez EA (1991) Tightness of the perianth of coconuts in relation to infestation by coconut mite. Fla Entomol 74:358-361

Keifer HH (1965) Eriophyid studies B-14. California Department of Agriculture, Bureau of Entomology, $20 \mathrm{pp}$

Lawson-Balagbo LM, Gondim MGC Jr, de Moraes GJ, Hanna R, Schausberger P (2007) Refuge use by the coconut mite Aceria guerreronis: fine scale distribution and association with other mites under the perianth. Biol Control 43:102-110

Lesna I, Conijn CGM, Sabelis MW (2004) From biological control to biological insight: Rust-mite induced change in bulb morphology, a new mode of indirect plant defense? Phytophaga 14:1-7

Mariau D (1977) Aceria (Eriophyes) guerreronis: un important ravageur des coco tereraies africaines et américaines. Oléagineux 32:101-111

Mariau D (1986) Comportement de Eriophyes guerreronis Keifer à l'égard de diferentes variétés de cocotier. Oléagineux 41:499-505

Mariau D, Julia JF (1970) L'acariose à Aceria guerreronis (Keifer) ravageur du cocotier. Oléagineux 25:459464

Moore D (1986) Bract arrangement in the coconut fruit in relation to attack by the coconut mite Eriophyes guerreronis Keifer. Trop Agric (Trinidad) 63:285-288

Moore D, Alexander L (1987) Aspects of migration and colonization of the coconut palm by the coconut mite, Eriophyes guerreronis (Keifer) (Acari: Eriophyidae). Bull Entomol Res 77:641-650

de Moraes GJ, Lopes PC, Fernando LCP (2004) Phytoseiid mites (Acari: Phytoseiidae) of coconut growing areas in Sri Lanka, with description of three new species. J Acarol Soc Japan 13(2):141-160

Navia D, de Moraes GJ, Roderick G, Navajas M (2005) The invasive coconut mite, Aceria guerreronis (Acari: Eriophyidae): invasion and origin sources inferred from mitochondrial (16S) and nuclear (ITS) sequences. Bull Entomol Res 95:505-516

Oku K, Yano S, Takafuji A (2003) Spider mite's use of a refuge during the quiescent stage in the presence of a predator. Entomol Exp Appl 108:72-74

Ramaraju K, Natarajan K, Sundara Babu PC, Palanisamy S, Rabindra RJ (2002) Studies on coconut eriophyid mite, Aceria guerreronis Keifer in Tamil Nadu, India. In: Fernando LCP, de Moraes GJ, Wickramananda IR (eds) Proceedings of the International Workshop on Coconut mite (Aceria guerreronis), Coconut Research Institute, Sri Lanka, January 6-8 2000. Coconut Research Institute, Sri Lanka

Sabelis MW, Bruin J (1996) Evolutionary ecology: life history patterns, food plant choice and dispersal. In: Lindquist EE, Sabelis MW, Bruin J (eds) Eriophyoid mites-their biology, natural enemies and control. World crop pest series, vol 6. Elsevier Science Publishers, Amsterdam, pp 329-366 
Sabelis MW, Takabayashi J, Janssen A, Kant MR, van Wijk M, Sznajder B, Aratchige NS, Lesna I, Belliure B, Schuurink RC (2007) Ecology meets plant physiology: herbivore-induced plant responses and their indirect effects on arthropod communities. In: Ohgushi T, Craig TP, Price PW (eds) Ecological communities: plant mediation in indirect interaction webs. Cambridge University Press, Cambridge, pp $188-217$

Wiackowski K, Starońska A (1999) The effect of predator and prey density on the induced defence of a ciliate. Funct Ecol 13:59-65 